University of Nebraska - Lincoln

DigitalCommons@University of Nebraska - Lincoln

Investigations of the Ichthyofauna of

Nicaraguan Lakes

1976

Body Fluid Solutes of Juveniles and Adults of the Euryhaline Bull Shark Carcharhinus Leucas from Freshwater and Saline Environments

\author{
Thomas B. Thorson \\ University of Nebraska-Lincoln \\ C. Michael Cowan \\ Associated Environmental Services Corp. \\ Donald E. Watson \\ University of Lagos
}

Follow this and additional works at: https://digitalcommons.unl.edu/ichthynicar

Part of the Aquaculture and Fisheries Commons

Thorson, Thomas B.; Cowan, C. Michael; and Watson, Donald E., "Body Fluid Solutes of Juveniles and Adults of the Euryhaline Bull Shark Carcharhinus Leucas from Freshwater and Saline Environments" (1976). Investigations of the Ichthyofauna of Nicaraguan Lakes. 47.

https://digitalcommons.unl.edu/ichthynicar/47

This Article is brought to you for free and open access by the Papers in the Biological Sciences at DigitalCommons@University of Nebraska - Lincoln. It has been accepted for inclusion in Investigations of the Ichthyofauna of Nicaraguan Lakes by an authorized administrator of DigitalCommons@University of Nebraska Lincoln. 
Reprinted for private circulation from PHysiological Zoölogy, Vol. 46, No. 1, January 1973, pp. 29-42 Copyright (C) 1973 by the University of Chicago. All rights reserved. Printed in U. S. A.

\section{BODY FLUID SOLUTES OF JUVENILES AND ADULTS OF THE EURYHALINE BULL SHARK CARCHARHINUS LEUCAS FROM FRESHWATER AND SALINE ENVIRONMENTS ${ }^{1}$}

THOMAS B. THORSON, C. MICHAEL COWAN, AND DONALD E. WATSON

Department of Zoölogy, University of Nebraska, Lincoln, Nebraska 68508; Department of

Biology, Nebraska Wesleyan University, Lincoln, Nebraska 68504; and School of Biological Sciences, University of Lagos, Yaba, Lagos, Nigeria

\section{INTRODUCTION}

Since the discovery of the phenomenally high urea content of the body fluids of cartilaginous fishes by Staedeler and Frerichs (1858), the unique osmoregulatory system of this vertebrate class has been studied by many investigators. In broad outline, the mechanisms are essentially similar in all three of the major subtaxa: the selachians, the batoids, and the holocephalans. A single exception is the genus Potamotrygon (fresh-water stingrays of South America and Africa), which has apparently lost the ability to concentrate urea even when transferred to salt water (Thorson, Cowan, and Watson 1967; Thorson 1970; Goldstein and Forster $1971 b)$.

Since the Chondrichthyes are primarily marine animals, research on them has centered mainly upon marine species, either in their natural environment or following transfer to various dilutions of seawater. These studies have been reviewed by Smith $(1931 b, 1936)$,

\footnotetext{
$1 \mathrm{We}$ are indebted to Colegio Centro America, Managua, Nicaragua, for facilities provided. Some of the laboratory work was done by Jeffery W. Gerst. Appreciation is expressed to him and to others too numerous to name for a variety of help. The study was supported by NIH grant HE-09075, by National Science Foundation funds for operation of the $R / V$ Rhincodon at the Mote Marine Laboratory, and by the University $\mathrm{Re}$ search Council of the University of Nebraska, through Biomedical Sciences Support Grant RT07055.
}

Krogh (1939), Prosser and Brown (1961), Potts and Parry (1964), several authors in Gilbert, Mathewson, and Rall (1967), and Hoar and Randall (1969).

However, chondrichthians have also been reported in brackish or fresh water in many places around the world, particularly in the tropics and subtropics. Known occurrences have been tabulated by Engelhardt (1913), Smith (1936), and Boeseman (1964). These species are, to various extents, euryhaline and should provide excellent subjects for studies on osmoregulation. Yet, in spite of the ready availability of euryhaline forms in certain places, very little work has been done on any aspect of the physiology of elasmobranchs in fresh water until the past decade. The only exception was the classical investigation of Smith (1931a) who studied the blood and certain other body fluids of four species of elasmobranchs taken in the Perak River in the Federated Malay States (now Malaysia). These included a sawfish, Pristis microdon; a shark identified as Carcharhinus melanopterus; and two rays, Dasyatis warnak and Hypolophus sephen. For more than 30 years Smith's results provided the only available basis for subsequent discussions of osmoregulation of elasmobranchs in fresh water. In general, Smith demonstrated that (1) the osmotic pressure of the serum is 
about $45 \%$ lower in fresh-water elasmobranchs than in marine ones but is still higher than that of either freshwater or marine teleosts; (2) in fresh water, chloride content is reduced by about $25 \%$, to approximately the range of teleosts; (3) the urea level is lower by about $70 \%$, but still much higher than that of teleosts; and (4) urine exhibits a marked increase in flow accompanied by a manyfold decrease in osmotic concentration.

Values reported by Smith (1931a) for urea, as well as other body fluid parameters, varied widely both among and within species. This has also been true for marine elasmobranchs reported by other authors. These variations no doubt represent, in part, genuine specific differences, and in some cases might reflect technical problems. However, in many cases (Smith excepted), the environmental history of the subject animals was unknown, or at least not indicated, and the variations in urea levels reported may to some extent reflect differences in the salinity of the environment from which the experimental animals were taken.

The ideal experimental subject would be one that could be taken from both fresh and salt water, in situations where it was reasonably certain that the individuals had been in one environment or the other for an appreciable length of time. Such a species is Carcharhinus leucas (family, Carcharhinidae), the bull shark, which occurs along the coasts of tropical and subtropical land masses all around the world. This species occurs in full-strength seawater and also congregates around the mouths of rivers and is known to travel up completely fresh-water rivers and into lakes in a number of places. Although the listings mentioned above include several species of sharks reported in fresh water, the only sharks that commonly undertake extended excursions into fresh water in appreciable numbers are Carcharhinus leucas and its close relatives included in the C. leucas-gangeticus group of Garrick and Schultz (1963). Carcharhinus leucas is the species that forms a sizable population in Lake Nicaragua and its drainage into the Caribbean Sea, the Rio San Juan. Contrary to an earlier and still common popular belief, they do not constitute a separate, land-locked species but are identical with the bull sharks of the Atlantic and are able to move freely back and forth between the Caribbean Sea and Lake Nicaragua (Thorson, Watson, and Cowan 1966; Thorson 1971). They are also known to remain in both fresh and salt water for extended periods (unpublished data). In spite of its potential usefulness and availability, $C$. leucas remained unexploited for physiological studies until 1962. Since that time, studies on various aspects of the osmoregulation of this species have been reported by Thorson (1962a, 1962b, 1967), Urist (1962), Oguri (1964), Gerzelli, Gervaso, and De Stefano (1969), and Thorson and Gerst (1972).

In this paper, we present data on the chemical anatomy of serum, perivisceral fluid, pericardial fluid, and cranial fluid of (1) adult sharks from marine waters off the west coast of Florida; (2) adults from the fresh water of Lake Nicaragua; (3) juveniles from the fresh water of the lowest reaches of the Rio San Juan; and (4) adults from water of undetermined but varied salinities around the mouth of the Rio San Juan.

\section{MATERIAL AND METHODS}

The sharks were obtained by local fishermen in Lake Nicaragua and at 


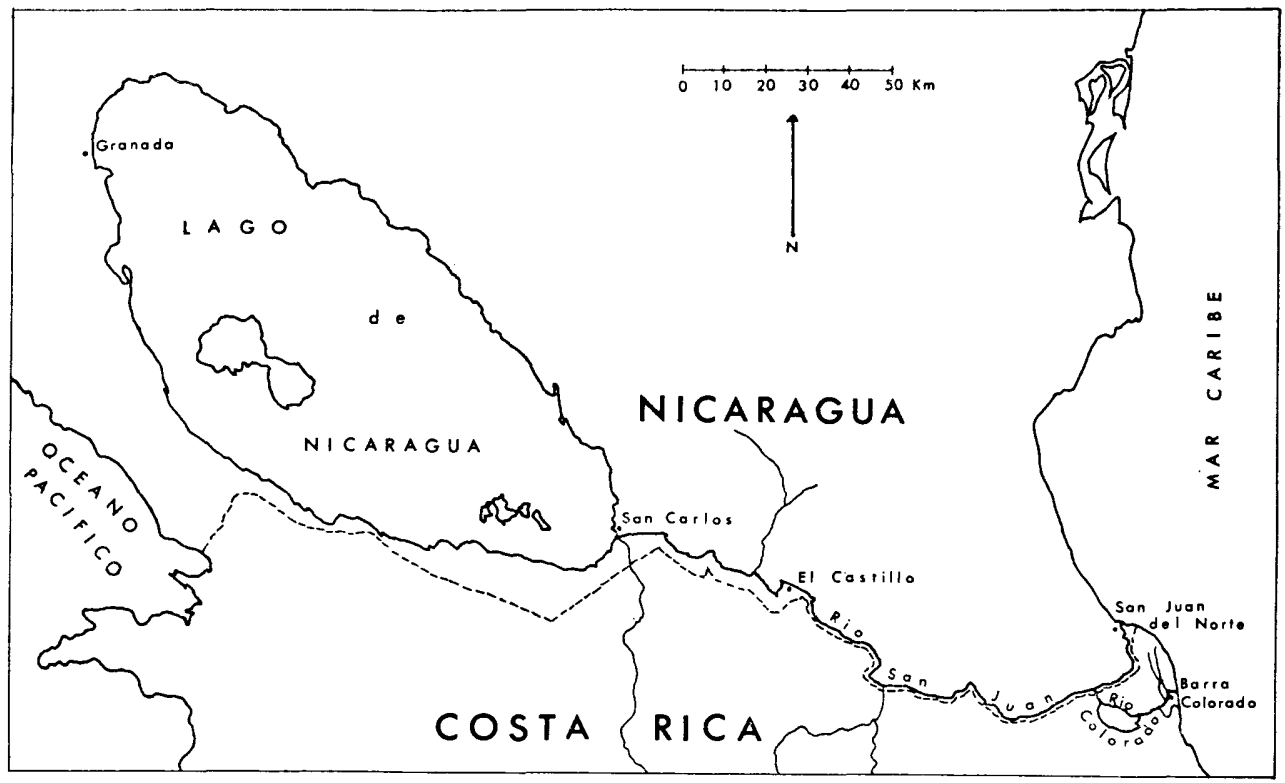

FIg. 1.-Map of Lake Nicaragua, Rio San Juan, and Rio Colorado (drawn by Norman H. Jensen)

Barra del Colorado, Costa Rica (fig. 1). They were caught almost exclusively on handlines with large shark hooks baited with chunks of various local fishes. A few in the vicinity of Granada were taken on sport gear with caiman tail as bait. The Florida sharks were taken on longlines, also baited with chunks of fish.

Here, adults include both sexually mature and immature individuals, in most cases more than $110 \mathrm{~cm}$ long, while juveniles are $72 \mathrm{~cm}$ or less in length. Very few sharks between 80 and $110 \mathrm{~cm}$ in length are taken in the research area.

The adult series from Florida was taken in full-strength seawater of approximately $34 \mathrm{ppt}$ total salinity, within a few miles of the Mote Marine Laboratory at Sarasota.

The water of Lake Nicaragua is completely fresh. The lake is about $165 \mathrm{~km}$ long, while the Rio San Juan-Rio Colorado system is somewhat longer. The Lake Nicaragua series of sharks in- cluded a group of specimens taken at each end of the lake (near Granada and at San Carlos). They were, therefore, about $180-345 \mathrm{~km}$ from the sea, distances that assure that they had been in fresh water for an appreciable, although undetermined, length of time. Since the major fluid parameters showed no differences between the two groups, they have been combined in a single series.

The juvenile series was taken almost exclusively a kilometer or more inside the river mouth, where the water was completely fresh, as it is throughout the length of the Rio San Juan and Rio Colorado.

After leaving the river mouth, the fresh water extends 2 or $3 \mathrm{~km}$ out to sea and is washed down the coast by the prevailing current and gradually dissipates. Therefore, the surface water immediately outside the mouth is fresh, although there may at times be an intrusion of brackish water underneath. In any case, all adult sharks taken near 
the river mouth were probably caught in fresh water, since fishing could only be done from the small dugouts employed, in relatively calm water, and the fishermen rarely ventured as far as the salt-water intrusion. However, it is conceivable that a few may have been taken from the deeper, brackish-water underlayer. Preliminary tagging and telemetry results (Thorson 1971; unpublished data) indicate free movement of sharks up and down the coast, in and out the river mouth, and up and down the river. Thus, the environmental background of the series of sharks taken at the river mouth is undoubtedly heterogeneous, and even though caught in fresh water they may very recently have come from salt water, or, in some cases, possibly from the lake.

Field collection of body fluids was carried out in the summers of 19651970. In 1965, a complete field laboratory was set up at Colegio Centro America, Granada, Nicaragua, and all laboratory analyses were completed as the samples became available. In subsequent years, more limited facilities were set up at Barra del Colorado, Costa Rica, where hematocrit, $p \mathrm{H}$, and bicarbonate were determined. Fluid samples were then frozen and shipped on dry ice to our Lincoln, Nebraska, laboratory, where most of the analyses were performed. This procedure was also followed with the marine specimens at the Mote Marine Laboratory. Fluids from all but two fresh-water specimens were analyzed in our field laboratory in Nicaragua. All others were done in Lincoln. Essentially the same equipment and methods were employed in both places, and no appreciable differences were noted between analyses made in the two situations.

All fluids were drawn from their respective sources by needle and syringe, in the case of blood, from a caudal vessel or by cardiac puncture. Blood was allowed to clot, and serum was removed following centrifugation.

Sodium, potassium, and calcium were determined by flame photometry; magnesium by the titan yellow method of Heagy (1948); chloride by mercuric nitrate titration, modified from Schales and Schales (1941); bicarbonate by the method of Scribner and Caillouette (1954); inorganic phosphorus by a method based on Fiske and Subbarow (1925); total protein by the biuret method (after Weichselbaum 1946); urea by the Nessler reaction, the carbamido diacetyl reaction, modified from Fearon (1939), or by the microdiffusion method of Conway and O'Malley (1942); trimethylamine oxide by a method based on Dyer, Dyer, and Snow (1952). The $p H$ was read on an Instrumentation Laboratory Delta-matic model $145 \mathrm{pH} / \mathrm{mV}$ electrometer.

\section{DISCUSSION OF RESULTS}

Table 1 summarizes data for the four series of sharks. It should be borne in mind when interpreting comparisons that the sample size of the marine series is smaller than that of the other series and that ranges of some parameters are appreciable.

Solute concentrations are expressed in $\mathrm{mm}$ /liter, except total protein which is recorded in grams percent. Partial data for the adult fresh-water series from Lake Nicaragua were previously presented by Thorson (1967).

SERUM SOLUTES

The total concentration of all measured serum solutes of the marine series is a little more than $1,000 \mathrm{~mm} /$ liter, approximately what would be expected of elasmobranchs in seawater, as previ- 
ously reported. In the fresh-water series it is approximately two-thirds of the marine level.

Of the individual parameters, potassium, calcium, bicarbonate, phosphorus, and total protein show very little difference between the fresh-water and marine series, whereas the fresh-water magnesium level is about $37 \%$ of the marine level, the total of sodium and chloride is about $80 \%$ and urea about $47 \%$.

Differences are somewhat less pronounced than those reported between fresh-water and marine elasmobranchs by Smith $(1931 a, 1931 b, 1936)$. However, his comparisons were between different species, and it is well established that there are appreciable species differences completely unrelated to habitat.

In Urist's (1962) comparison of Carcharhinus leucas nicaraguensis (from fresh water) with marine $C$. l. leucas, mean figures for sodium, chloride, and urea suggested somewhat lower levels than ours for fresh-water sharks. However, he used only four specimens, and his figures in most cases fall within the low part of our ranges. No important differences are evident. Urist's figures for marine sharks, based on a small but unspecified number of specimens, are likewise largely within our ranges. However, his values for sodium (223.4 mM/ liter) and chloride (236) are well below our ranges (276-300 and 267-309, respectively) as well as below most values given by other investigators for elasmobranchs (summarized by Bernard, Wynn, and Wynn 1966).

Gerzelli et al. (1969) reported data on three $C$. leucas from Lake Nicaragua and two from "the sea." The latter were taken at the mouth of the Rio Colorado and are therefore comparable with our estuarine series, which were of unknown but probably mixed environmental history. Their fresh-water specimens had $198 \mathrm{~mm} /$ liter sodium, 234 $\mathrm{mm} /$ liter chloride, and $231 \mathrm{~mm} /$ liter urea. The sodium and chloride were, in general, similar to ours, but the urea content was higher than that of any of our specimens from the lake. The "marine" (estuarine) specimens had $213 \mathrm{~mm} /$ liter sodium, $360 \mathrm{~mm} /$ liter chloride, and $435 \mathrm{~mm} /$ liter urea. In this case, the urea was at the high end of our marine range, but the sodium was far below any individual sodium value found in our marine series and at the low extreme for all others. The chloride was well above any individual in any of our series.

Our estuarine series predictably is highly variable. Ranges of the inorganic ions so broadly overlap those of the other series that little confidence can be placed in the apparent differences. The individual urea levels range from well below the fresh-water average (157 compared with $169 \mathrm{~mm}$ /liter to approximately the marine average ( 357 compared with $356 \mathrm{~mm} /$ liter). A similar range of urea levels (134-336 mm/ liter) was found in a series of eight pregnant females taken from the same collecting grounds at Barra del Colorado (Thorson and Gerst 1972). From tagging and tracking records (unpublished data) it is known that these sharks move freely in and out of the river mouth and from fresh water to salt water and vice versa. They are highly tolerant of either fresh or salt water for extended periods of time. Since they are strong swimmers and are constantly moving, it is a reasonable assumption that they are not confined to a narrow range of salinity, even for short periods. It is impossible to know, even if the exact spot of capture is known, where they have been in the im- 
TABLE 1

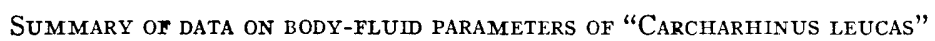

\begin{tabular}{|c|c|c|c|c|c|c|}
\hline Body Fluid & Hematocrit & $p \mathrm{H}$ & $\mathrm{Na}$ & $\mathrm{k}$ & $\mathrm{Ca}$ & $\mathrm{Mg}$ \\
\hline \multicolumn{7}{|l|}{ Marine adults (Florida): } \\
\hline Serum $\ldots$ & $\begin{array}{l}21.6(6) \\
18-27 \\
1.31\end{array}$ & $\begin{array}{l}7.00(4) \\
6.81-7.15 \\
0.08\end{array}$ & $\begin{array}{c}288(7) \\
276-300 \\
3.54\end{array}$ & $\begin{array}{l}\quad 6.1(6) \\
5.0-8.0 \\
0.47\end{array}$ & $\begin{array}{l}5.7(7) \\
4.1-6.3 \\
0.29\end{array}$ & $\begin{array}{l}3.8(7) \\
1.7-6.0 \\
0.59\end{array}$ \\
\hline Perivisceral fluid & $\cdots$ & $\begin{array}{l}5.36(2) \\
5.32-5.39\end{array}$ & $\begin{array}{c}313(5) \\
290-328 \\
8.21\end{array}$ & $\begin{array}{l}6.7(5) \\
4.2-10.6 \\
1.11\end{array}$ & $\begin{array}{l}1.7(4) \\
1.2-2.6 \\
0.32\end{array}$ & $\begin{array}{l}3.3(4) \\
2.5-5.3 \\
0.70\end{array}$ \\
\hline Pericardial fluid $\ldots \ldots \ldots$ & $\cdots$ & $\begin{array}{l}5.05(2) \\
5.00-5.10\end{array}$ & $\begin{array}{l}336(5) \\
308-370 \\
11.89\end{array}$ & $\begin{array}{l}11.6(5) \\
9.6-16.9 \\
1.41\end{array}$ & $\begin{array}{l}2.4(5) \\
2.2-2.8 \\
0.11\end{array}$ & $\begin{array}{l}1.8(5) \\
1.4-2.6 \\
0.22\end{array}$ \\
\hline Cranial fluid $\ldots \ldots \ldots$ & $\ldots$ & $\begin{array}{l}7.26(3) \\
7.02-7.42 \\
0.12\end{array}$ & $\begin{array}{l}266(4) \\
231-278 \\
11.59\end{array}$ & $\begin{array}{l}3.7(4) \\
2.1-4.6 \\
0.57\end{array}$ & $\begin{array}{l}4.6(4) \\
4.2-5.1 \\
0.18\end{array}$ & $\begin{array}{l}3.0(4) \\
1.9-4.0 \\
0.47\end{array}$ \\
\hline \multicolumn{7}{|l|}{$\begin{array}{l}\text { Fresh-water adults (Lake } \\
\text { Nicaragua): }\end{array}$} \\
\hline Serum $\ldots \ldots \ldots \ldots$ & $\begin{array}{l}24.9(8) \\
19-29 \\
1.30\end{array}$ & $\begin{array}{l}6.83(15) \\
6.28-7.15 \\
0.06\end{array}$ & $\begin{array}{c}245(17) \\
214-280 \\
4.14\end{array}$ & $\begin{array}{l}6.4(12) \\
5.0-8.2 \\
0.29\end{array}$ & $\begin{array}{l}4.5(15) \\
3.5-5.3 \\
0.15\end{array}$ & $\begin{array}{l}1.4(16) \\
0.9-2.3 \\
0.09\end{array}$ \\
\hline Perivisceral fluid..$\ldots \ldots$ & $\ldots$ & $\begin{array}{l}5.50(7) \\
5.26-5.85 \\
0.07\end{array}$ & $\begin{array}{l}213(7) \\
186-236 \\
6.64\end{array}$ & $\begin{array}{l}5.8(7) \\
4.8-6.4 \\
0.22\end{array}$ & $\begin{array}{l}0.8(6) \\
0.5-1.6 \\
0.18\end{array}$ & $\begin{array}{l}1.8(6) \\
1.0-2.3 \\
0.18\end{array}$ \\
\hline Pericardial fluid $\ldots \ldots \ldots$ & $\ldots$ & $\begin{array}{l}5.57(11) \\
5.04-5.95 \\
0.08\end{array}$ & $\begin{array}{l}249(11) \\
198-276 \\
6.23\end{array}$ & $\begin{array}{l}11.1(8) \\
5.5-15.6 \\
1.05\end{array}$ & $\begin{array}{l}1.4(11) \\
0.6-1.9 \\
0.13\end{array}$ & $\begin{array}{l}1.5(13) \\
1.0-2.2 \\
0.11\end{array}$ \\
\hline Cranial fluid $\ldots \ldots \ldots$ & $\cdots$ & $\begin{array}{l}7.49(13) \\
7.01-7.97 \\
0.08\end{array}$ & $\begin{array}{l}247(11) \\
206-268 \\
5.96\end{array}$ & $\begin{array}{l}\quad 4.8(10) \\
4.2-5.4 \\
0.12\end{array}$ & $\begin{array}{l}3.1(10) \\
2.2-3.8 \\
0.19\end{array}$ & $\begin{array}{l}1.6(11) \\
1.2-2.3 \\
0.10\end{array}$ \\
\hline \multicolumn{7}{|l|}{$\begin{array}{l}\text { Fresh-water juveniles } \\
\text { (lower Rio Colorado): }\end{array}$} \\
\hline Serum $\ldots \ldots \ldots \ldots \ldots$ & $\begin{array}{l}21.8(9) \\
18-25 \\
0.76\end{array}$ & $\cdots$ & $\begin{array}{c}228(12) \\
204-262 \\
4.45\end{array}$ & $\begin{array}{l}6.3(12) \\
4.4-9.8 \\
0.43\end{array}$ & $\begin{array}{l}4.3(5) \\
2.7-5.3 \\
0.46\end{array}$ & $\begin{array}{l}2.1(5) \\
1.6-2.5 \\
0.17\end{array}$ \\
\hline \multicolumn{7}{|l|}{$\begin{array}{l}\text { Estuarine adults (mouth } \\
\text { of Rio Colorado): }\end{array}$} \\
\hline Serum $\ldots \ldots$ & $\begin{array}{l}22.5(19) \\
13-31 \\
1.20\end{array}$ & $\begin{array}{l}6.71(13) \\
6.45-7.20 \\
0.06\end{array}$ & $\begin{array}{c}233(29) \\
196-270 \\
2.97\end{array}$ & $\begin{array}{l}5.9(29) \\
3.9-13.2 \\
0.37\end{array}$ & $\begin{array}{l}4.2(27) \\
2.0-5.4 \\
0.17\end{array}$ & $\begin{array}{l}2.0(28) \\
1.4-2.9 \\
0.03\end{array}$ \\
\hline Perivisceral fluid..$\ldots \ldots$ & $\cdots$ & $\begin{array}{l}5.41(8) \\
5.10-5.84 \\
0.10\end{array}$ & $\begin{array}{l}234(11) \\
198-278 \\
8.64\end{array}$ & $\begin{array}{l}5.3(11) \\
3.0-8.6 \\
0.42\end{array}$ & $\begin{array}{l}0.7(8) \\
0.4-1.6 \\
0.14\end{array}$ & $\begin{array}{l}2.9(8) \\
1.6-4.7 \\
0.35\end{array}$ \\
\hline Pericardial fluid..$\ldots \ldots$ & $\cdots$ & $\begin{array}{l}5.41(9) \\
5.12-5.73 \\
0.08\end{array}$ & $\begin{array}{l}255(9) \\
185-319 \\
12.33\end{array}$ & $\begin{array}{l}8.4(9) \\
4.2-12.4 \\
1.07\end{array}$ & $\begin{array}{l}1.1(11) \\
0.4-1.7 \\
0.14\end{array}$ & $\begin{array}{l}2.0(11) \\
1.1-3.0 \\
0.21\end{array}$ \\
\hline Cranial fluid $\ldots \ldots \ldots$ & $\ldots$ & $\begin{array}{l}7.39(9) \\
7.20-7.70 \\
0.05\end{array}$ & $\begin{array}{c}238(12) \\
209-254 \\
3.54\end{array}$ & $\begin{array}{l}4.7(12) \\
2.9-10.2 \\
0.66\end{array}$ & $\begin{array}{l}3.0(10) \\
1.3-4.3 \\
0.26\end{array}$ & $\begin{array}{l}1.5(13) \\
1.1-1.9 \\
0.06\end{array}$ \\
\hline
\end{tabular}

NoTE.-All fluid concentrations expressed in $\mathrm{mM} / \mathrm{liter}$ except total protein in $\mathrm{g} / 100$. The means, in italic, are followed by number of specimens in parentheses. Ranges are on the second line, followed by standard errors on the third.

mediate past. Price and Creaser (1967) found that the skate, Raja eglanteria, required more than $48 \mathrm{hr}$ to reach osmotic equilibrium when the salinity of its medium was changed by only 2.4 ppt. Changes in urea level in response to changed environmental salinity obviously are slow and will not accurately reflect short-term salinity changes. However, there can be no doubt that the animal's urea level is at least a crude indication of its more extended 
BODY FLUIDS OF BULL SHARKS

TABLE 1 (Continued)

\begin{tabular}{|c|c|c|c|c|c|c|}
\hline Body Fluid & $\mathrm{Cl}$ & $\mathrm{HCO}_{3}$ & $\mathrm{Pi}$ & $\begin{array}{c}\text { Total } \\
\text { Protein }\end{array}$ & Urea & TMAO \\
\hline \multicolumn{7}{|l|}{ Marine adults (Florida): } \\
\hline Serum $\ldots \ldots \ldots \ldots$ & $\begin{array}{c}288(7) \\
267-309 \\
5.96\end{array}$ & $\begin{array}{l}8.1(5) \\
6.0-10.0 \\
0.71\end{array}$ & $\begin{array}{l}2.3(4) \\
1.8-3.5 \\
0.41\end{array}$ & $\begin{array}{l}3.3(7) \\
2.4-3.9 \\
0.22\end{array}$ & $\begin{array}{l}356(7) \\
289-450 \\
20.90\end{array}$ & $\begin{array}{l}46.6(4) \\
30.7-53.6 \\
5.34\end{array}$ \\
\hline Perivisceral fluid ... & $\begin{array}{c}382(5) \\
366-400 \\
6.07\end{array}$ & $\begin{array}{l}5.0(2) \\
3.5-6.5\end{array}$ & $\begin{array}{l}0.3(5) \\
\text { Trace-1.1 } \\
0.22\end{array}$ & Trace & $\begin{array}{l}380(4) \\
328-443 \\
25.78\end{array}$ & $\cdots$ \\
\hline Pericardial fluid & $\begin{array}{l}372(5) \\
350-400 \\
8.33\end{array}$ & $\begin{array}{l}6.5(2) \\
6.0-7.0\end{array}$ & $\begin{array}{l}0.1(5) \\
\text { Trace-0.3 } \\
0.06\end{array}$ & Trace & $\begin{array}{l}418(4) \\
393-464 \\
15.77\end{array}$ & $\cdots$ \\
\hline Cranial fluid & $\begin{array}{c}279(4) \\
275-284 \\
2.46\end{array}$ & $\begin{array}{l}6.8(3) \\
4.5-8.5 \\
1.20\end{array}$ & $\begin{array}{l}1.5(4) \\
1.4-1.7 \\
0.07\end{array}$ & $\ldots$ & $\begin{array}{l}429(3) \\
410-450 \\
11.57\end{array}$ & $\ldots$ \\
\hline \multicolumn{7}{|l|}{$\begin{array}{l}\text { Fresh-water adults (Lake } \\
\text { Nicaragua): }\end{array}$} \\
\hline Serum $\ldots \ldots \ldots \ldots \ldots$ & $\begin{array}{c}219(17) \\
179-247 \\
4.91\end{array}$ & $\begin{array}{l}7.0(13) \\
5.0-9.0 \\
0.38\end{array}$ & $\begin{array}{l}2.6(10) \\
2.0-3.0 \\
0.10\end{array}$ & $\begin{array}{l}3.1(16) \\
2.5-3.6 \\
0.07\end{array}$ & $\begin{array}{c}169(16) \\
121-194 \\
5.40\end{array}$ & $\ldots$ \\
\hline Perivisceral fluid ... & $\begin{array}{l}217(7) \\
200-228 \\
3.75\end{array}$ & $\cdots$ & Trace & Trace & $\begin{array}{l}179(3) \\
129-208 \\
24.97\end{array}$ & $\cdots$ \\
\hline Pericardial fluid $\ldots \ldots \ldots$. & $\begin{array}{c}258(13) \\
221-293 \\
6.59\end{array}$ & $6.0(1)$ & Trace & Trace & $\begin{array}{l}161(3) \\
121-187 \\
20.42\end{array}$ & $\ldots$ \\
\hline Cranial fluid $\ldots \ldots \ldots \ldots$ & $\begin{array}{l}224(7) \\
192-250 \\
7.06\end{array}$ & $\begin{array}{l}6.6(7) \\
4.0-9.0 \\
0.39\end{array}$ & $\begin{array}{l}1.2(5) \\
0.8-1.6 \\
0.13\end{array}$ & $\begin{array}{l}1.2(11) \\
\text { Trace-1.9 } \\
0.17\end{array}$ & $\begin{array}{l}172(4) \\
136-207 \\
14.77\end{array}$ & $\ldots$ \\
\hline \multicolumn{7}{|l|}{$\begin{array}{l}\text { Fresh-water juveniles } \\
\text { (lower Rio Colorado): }\end{array}$} \\
\hline Serum $\ldots \ldots \ldots \ldots$ & $\begin{array}{l}207(12) \\
179-233 \\
5.15\end{array}$ & $\cdots$ & $\cdots$ & $\begin{array}{l}2.0(5) \\
1.8-2.4 \\
0.10\end{array}$ & $\begin{array}{c}138(12) \\
114-171 \\
6.01\end{array}$ & $\ldots$ \\
\hline \multicolumn{7}{|l|}{$\begin{array}{l}\text { Estuarine adults (mouth } \\
\text { of Rio Colorado): }\end{array}$} \\
\hline Serum $\ldots \ldots \ldots \ldots \ldots$ & $\begin{array}{c}233(29) \\
183-293 \\
4.06\end{array}$ & $\begin{array}{l}5.8(11) \\
4.0-8.0 \\
0.36\end{array}$ & $\begin{array}{l}2.7(18) \\
1.6-4.8 \\
0.17\end{array}$ & $\begin{array}{l}2.6(26) \\
1.2-3.8 \\
0.12\end{array}$ & $\begin{array}{c}220(28) \\
152-357 \\
9.82\end{array}$ & $\begin{array}{l}13.2(7) \\
8.9-23.3 \\
2.14\end{array}$ \\
\hline Perivisceral fluid & $\begin{array}{c}243(13) \\
196-270 \\
6.28\end{array}$ & $\begin{array}{l}5.9(6) \\
4.5-7.0 \\
0.35\end{array}$ & Trace & Trace & $\begin{array}{l}182(6) \\
160-209 \\
8.12\end{array}$ & $\ldots$ \\
\hline Pericardial fluid $\ldots \ldots \ldots \ldots$ & $\begin{array}{l}287(12) \\
208-375 \\
13.10\end{array}$ & $\begin{array}{l}5.9(8) \\
3.5-7.5 \\
0.45\end{array}$ & Trace & Trace & $\begin{array}{l}220(7) \\
157-286 \\
18.04\end{array}$ & $\cdots$ \\
\hline Cranial fluid ... & $\begin{array}{c}236(13) \\
198-270 \\
5.02\end{array}$ & $\begin{array}{l}8.8(9) \\
7.0-11.5 \\
0.48\end{array}$ & $\begin{array}{l}1.7(11) \\
1.2-2.2 \\
0.11\end{array}$ & $\begin{array}{l}1.1(11) \\
0.6-1.9 \\
0.11\end{array}$ & $\begin{array}{l}213(9) \\
147-264 \\
14.86\end{array}$ & $\begin{array}{l}16.2(2) \\
13.1-19.3\end{array}$ \\
\hline
\end{tabular}

environmental history. Since each animal of the estuarine series had its own peculiar but unknown history, the grouping is actually an artificial one, but it did not seem warranted to list the data for 29 sharks individually.

Trimethylamine oxide levels can be compared only between the marine series (46.6 mM/liter) and the estuarine series (13.2 mm/liter). Although our figures are lower than those frequently attributed to elasmobranchs, they agree with the findings of Goldstein, Oppelt, and Maren (1968) who found that, in the lemon shark (Negaprion brevirostris), TMAO concentration dropped by 
about $60 \%$ when the fish were transferred from full-strength to halfstrength seawater.

The 12 juvenile specimens range from newly born individuals with the umbilical scar still unhealed to those possibly several months of age. Their size range $(56-72 \mathrm{~cm})$ is entirely within the range of unborn pups of this species (Jensen 1972). Although they move freely about the fresh-water channels of the Rio San Juan-Rio Colorado system, they are concentrated in Laguna Agua Dulce, a shallow channel about 12 $\mathrm{km}$ long, which runs parallel to the Caribbean Coast toward the north from the mouth of the Rio Colorado. Most of the 12 specimens were taken from this channel.

Most serum parameters of the juvenile series, including urea, were similar to, or slightly below, those of the adult fresh-water series, suggesting a freshwater habitat as the preferred environment of the neonatal sharks. This is borne out by 5 years' fishing records, which indicated that over $99 \%$ of more than 1,000 neonatal sharks were taken at points inside the river mouth, in strictly fresh water (unpublished data).

The ability to tolerate marine levels of urea is clearly present in this species before birth. Ex utero pups taken from females with urea levels ranging from 134 to $336 \mathrm{~mm} /$ liter, usually contained similar urea levels in their own serum (Thorson and Gerst 1972). It would appear that they should be able to live in either fresh or marine water at birth. The actual habitat selection is probably less a physiologic requirement than a matter of survival from predation. The heaviest concentration of adults, including a few other species of sharks, is around the river mouth, while in the "nursery grounds" of Laguna Agua
Dulce the juveniles are at least loosely segregated from the adults.

A lower protein content was noted in juvenile serum than in adult serum from either fresh or salt water. The same observation was reported in ex utero pups by Cowan (1971) and by Thorson and Gerst (1972).

PERIVISCERAL, PERICARDIAL, AND CRANIAL FLUIDS

Both perivisceral and pericardial cavities are parts of the coelomic system. Their fluids are regarded basically as secretions of their bounding membranes, the peritoneum and pericardium. The two cavities do not communicate, at least not freely and continuously (Smith 1929; Maren 1967), and each fluid has its own unique chemical anatomy. In all three adult series, both fluids had reduced calcium (especially in the perivisceral fluid) and only a trace of inorganic phosphorus and protein. As has been noted in other elasmobranchs by Smith (1929), Hartman et al. (1941), Rodnan, Robin, and Andrus (1962), and Bernard et al. (1966), chloride levels of both coelomic fluids were elevated above those of serum and cranial fluid. This was particularly true in the marine series. In fresh water, the chloride of perivisceral fluid dropped to the serum level, while pericardial chloride remained somewhat elevated. Sodium of both fluids in marine sharks was also slightly elevated but dropped to near the levels found in serum in fresh-water sharks. In all cases, sodium was somewhat higher in pericardial than in perivisceral fluid. The pericardial fluid had a potassium content greater than that of the other fluids by about a factor of 2 . This condition was also reported by Smith (1929) and by Maren (1967), but Bernard et al. (1966) reported high potassium in all fluids tested, with the 
least in pericardial fluid. We agree with Bernard et al. (1966) in that we did not observe the elevated magnesium in perivisceral fluid reported by Smith (1929) and by Hartman et al. (1941). In marine sharks, magnesium of perivisceral fluid was approximately the same as in serum. However, it was higher than that of pericardial fluid.

The cranial fluid of elasmobranchs lies between the brain and the cranium and is distinct from the cerebrospinal fluid, with which it has sometimes been confused. It was regarded by Smith as a protein-free dialysate of the plasma. We found it to be considerably more similar to serum than to the coelomic fluids, but it nevertheless had its own distinct chemical composition. We did not find that it was protein free but that it had approximately $40 \%$ of the serum protein concentration in both the freshwater and estuarine series. Oppelt et al. (1964) also reported approximately 1-2 $\mathrm{g} / 100$ protein in this fluid.

Our data do not appear either to support or disprove Smith's (1936) speculation that the perivisceral fluid provides an avenue of excretion. We occasionally noted the escape of coelomic fluid from the abdominal pores when sharks were brought on land and no longer had the pressure of the water supporting their bodies. However, we have no evidence that such a discharge takes place when the animals are in water.

In the fluids in general we did not find a reciprocal relation between concentration of inorganic substances and urea, as reported by Smith (1929). Urea content in the four fluids tested was, in general, similar. In marine sharks the minor fluids showed higher mean values for urea than did serum, but the ranges overlapped broadly. The minor fluids in general exhibited differences between the fresh-water and marine series similar to those shown by the serum.

HYDROGEN ION CONCENTRATION

The serum $p \mathrm{H}$ of the fresh-water, estuarine, and marine series of adults showed broadly overlapping ranges and were very little different from one another $(6.83,6.71$, and 7.00 , respectively). Values reported in the literature for a variety of elasmobranchs (cited by Bernard et al. 1966; Berger 1967; Maren 1967; Murdaugh and Robin 1967) largely fall between 7.2 and 7.6, although Bernard et al. (1966) gave figures of 6.0 for Dasyatis say and 6.3 and 6.9 for $D$. americana. Differences may be real and/or may depend on differences in procedures. Changes in $p \mathrm{H}$ occur slowly. Samples of cranial fluid tested 1,3 , and $5 \mathrm{hr}$ after being drawn had $p \mathrm{H}$ readings of $7.3,7.4$, and 7.5 in one instance and 7.2, 7.3, and 7.35 in another. Serum with a $p \mathrm{H}$ of 6.79 had a reading of 6.96 on the following day. Readings in the present study were taken on serum as soon as possible after clot separation and in other fluids as soon as possible after samples were collected.

Both coelomic fluids (perivisceral and pericardial) had appreciably higher hydrogen ion concentrations (ca. 5.05.5) than the serum. They were essentially the same in all three environmental series. This greater acidity has also been reported by others who have made observations on coelomic fluids of various elasmobranchs (Smith 1929; Rodnan et al. 1962; Bernard et al. 1966; Maren 1967).

The cranial fluid in all three series exhibited a hydrogen ion concentration lower than that of the serum (approximately 7.25-7.50), although in most respects this fluid is similar to the serum. Smith (1929) reported $p \mathrm{H}$ 
values for the cranial fluid of several species which were about the same as ours. However, his cranial fluid $p \mathrm{H}$ values were nearly the same as those of the plasma, which were somewhat lower (less acid) than our serum values.

\section{HEMATOCRIT}

When the Lake Nicaragua series is combined with the juvenile series from the fresh-water nursery area, the average fresh-water hematocrit value is 23.3 compared with 21.6 for the marine series. The mixed estuarine population is intermediate, with 22.5. This relationship is the reverse of what might have been anticipated between hydrating and dehydrating environments. However, these figures, for a single species, are in close agreement with figures of Thorson (1962b), comparing fresh-water Carcharhinus nicaraguensis (= leucas), with a hematocrit of 22.8 , with three basically marine species of sharks with a hematocrit of 18.9. The same relationship was also found by Thorson (1961) in a comparison of the hematocrits of three species of freshwater teleosts with seven marine teleost species (31.8 and 30.4, respectively). In none of these comparisons are the differences great enough to be statistically valid, but they demonstrate that the fresh-water environment does not elicit dilution of the plasma in species that can normally inhabit fresh-water.

\section{CONCLUDING REMARKS}

The wide range of urea concentrations in our estuarine series and the implied diversity of salinity from which the individual animals were taken underscore the importance of knowing the environmental history of the subjects before interpretations are made. Also, differences in physiological responses reported here and by various other investigators emphasize the need for considering the subject species' degree of euryhalinity.

To illustrate, Alexander et al. (1968), studying Scyliorhinus canicula, placed these dogfish in 60\% seawater and noted a rapid increase in weight which was attributed to retention of water. They calculated that the decrease in urea concentration observed in dogfish kept in diluted seawater could be explained entirely by dilution of the body fluids as water was taken up. They found no support for Smith's (1936) assumption that elasmobranchs respond to a diuretic stress by increased urea excretion. Furthermore, they (as well as Watts and Watts 1966) reported an increase in activity of carbamoyl phosphate synthetase (and presumably urea synthesis) in $S$. canicula placed in diluted seawater. These observations are undoubtedly true for the species in question. However, one must keep in mind that $S$. canicula is not a markedly euryhaline shark. It is possible that it may make excursions into somewhat brackish water, but its performance in diluted seawater clearly marks it as relatively stenohaline. These fish survived in $60 \%$ seawater only up to $10 \mathrm{hr}$ (Alexander et al. 1968). Although they survived for 2 or 3 days when transferred gradually to $80 \%$ seawater (Watts and Watts 1966), even then they showed signs of distress, in stiffness of the tail, difficulty of tail flexion, and imbibition of large amounts of sea water.

Somewhat different observations were reported by Goldstein and Forster (1971a) who successfully transferred Raja erinacea, over a period of 4 days, to approximately $50 \%$ seawater, kept them in this medium for 4 days, and returned them during an additional 4 days 
to full strength seawater. They reported that, as salinity of the medium was reduced, plasma urea concentration dropped, because of increased renal clearance; and urea synthesis decreased rather than increased. It is obvious from the survival of the subjects that this species is somewhat more tolerant of salinity changes than $S$. canicula. However, it was apparently approaching its limit of tolerace to dilution of its medium as suggested by an $18 \%$ increase in body weight and a $20 \%$ drop in hematocrit. No calculations were made to determine whether or not the drop in urea concentration could be explained on the basis of body-fluid dilution.

Goldstein et al. (1968) also transferred lemon sharks (Negaprion brevirostris) to $50 \%$ seawater over a period of 7 days and maintained them in that salinity for an additional 7 days. They ascribed an observed drop in urea concentration in the plasma to a nearly threefold increase in urea clearance from the body fluids and reported no significant change in the rate of urea synthesis. There was likewise no significant change in hematocrit, indicating that water balance was being maintained. These sharks are among the more euryhaline species and are known to occur in brackish and even fresh water (Bigelow and Schroeder 1948), although there are no known populations that regularly occur in fresh water for extended periods.

The fully euryhaline shark, Carcharhinus leucas, as reported above, occurs regularly in fresh water as well as in seawater for extended periods, and reported hematocrit values indicate that there is no dilution of body fluids when the animals enter fresh water. Furthermore, in a study by Thorson (1962a, $1962 b$ ), the total body water of $C$. leu- cas from Lake Nicaragua was shown to be virtually identical $(72.1 \%$ of body weight) with the average of three marine species, Negaprion brevirostris, Ginglymostoma cirratum, and Squalus acanthias $(71.5 \%)$. Also in that study, the pattern of water partitioning among the major body-fluid compartments was found to be similar in the fresh-water and marine sharks. The homeostatic mechanisms appear to be highly effective as regards water content and partitioning in spite of the radically different external medium and the resultant difference in osmoregulatory requirements.

Most of the findings concerning fresh-water elasmobranchs by Smith $(1931 a, 1936)$ were made on the sawfish, Pristis microdon, a species either identical with or closely related to $P$. perotteti, which occurs in Lake Nicaragua. Although it is also found in coastal salt and brackish water, it appears to spend major portions of its life in fresh water, probably reproducing there, and is, if anything, even more thoroughly adapted to fresh water than $C$. leucas (unpublished data). Smith's results must be interpreted in light of these facts. His assumption that elasmobranchs respond to a diuretic stress by increased urea excretion (supported by Goldstein et al. [1968] in Negaprion brevirostris) is undoubtedly valid for elasmobranchs equipped to deal with this stress (euryhaline species), but quite possibly not for stenohaline species. The assumption is not even pertinent to the fresh-water stingrays (Potamotrygonidae) which have apparently abandoned the mechanisms for urea retention (Thorson et al. 1967; Thorson 1970; Goldstein and Forster $1971 b)$.

It is clear from these and other apparently conflicting reports concerning various aspects of the osmoregulation 
of a number of elasmobranchs that the range of environmental salinity tolerance of the species studied is very important. It must be considered in interpreting results and caution must be exercised in extrapolating findings to elasmobranchs in general.

\section{SUMMARY}

1. Comparisons were made between various chemical parameters of bullshark serum, perivisceral fluid, pericardial fluid, and cranial fluid from adults taken from marine water, adults from fresh water, juveniles from fresh water, and adults from a river mouth where environmental salinities of the subjects were unknown but probably heterogeneous.

2. Serum of fresh-water adults contained reduced levels of magnesium, sodium, chloride, and urea compared with marine adults, while potassium, calcium, bicarbonate, inorganic phosphorus, and total protein were approximately equal.

3. The estuarine series was highly variable. The serum urea content ranged from levels found in fresh-water specimens to those of marine ones. The urea concentration was interpreted as an index of the shark's recent environmental history.

4. Except for a reduced protein concentration, the juveniles' serum solute concentrations were similar to those of fresh-water adults. Even before birth, they have the urea tolerance necessary for life in a marine environment, but they occur mainly in fresh-water "nur- sery grounds," probably because they are segregated there from predatory adults rather than for physiologic reasons.

5. In comparison with serum, the coelomic fluids (perivisceral and pericardial) had elevated chloride levels, reduced calcium, and only a trace of inorganic phosphorus and protein. Sodium was somewhat higher in pericardial than in perivisceral fluid, and pericardial potassium concentration was greater by a factor of about 2 than in other fluids.

6. Cranial fluid was more similar to serum than to coelomic fluids, but its protein content was intermediate between them.

7. The minor fluids, in general, exhibited differences between the freshwater and marine series similar to those shown by the serum.

8. Hydrogen ion concentration was virtually the same in the three environments. However, the coelomic fluids were distinctly more acid than the serum, and the cranial fluid was less acid.

9. Mean hematocrit values were virtually equal in the fresh-water and marine series, indicating that osmotic dilution of fluids does not occur in the fresh-water environment.

10. The environmental history of experimental elasmobranchs and the range of environmental salinity tolerance of the subject species must be considered in interpreting experimental results, and great caution must be exercised in extrapolating results from one species to elasmobranchs in general.

\section{LITERATURE CITED}

Alexander, M. D., E. S. Haslewood, G. A. D. Haslewood, D. C. Watts, and R. L. Watts. 1968. Osmotic control and urea biosynthesis in selachians. Comp. Biochem. Physiol. 26: 971-978.
Bernard, G. R., R. A. Wynn, and G. G. Wynn. 1966. Chemical anatomy of the pericardial and perivisceral fluids of the stingray, Dasyatis americana. Biol. Bull. 130:18-27.

Bigelow, H. B., and W. C. Schroeder. 1948. 
Sharks. In Fishes of the western North Atlantic. Mem. Sears Found. Marine Res. Vol. 1, no. 2. Yale Univ., New Haven, Conn.

Bofseman, M. 1964. Notes on the fishes of western New Guinea. III. The fresh water shark of Jamoer Lake. Zool. Mededelingen 40:9-22.

Burger, J. W. 1967. Problems in the electrolyte economy of the spiny dogfish, Squalus acanthias. In P. W. GrberrT, R. F. Mathewson, and D. P. RALL (eds.), Sharks, skates, and rays. Johns Hopkins Press, Baltimore.

Conway, E. J., and E. O'Malley. 1942. Microdiffusion methods: ammonia and urea using buffered absorbents. Biochem. J. 36:655-661.

Cowan, C. M. 1971. Serum protein variation in the bull shark, Carcharhinus leucas Müller and Henle, 1841. Int. J. Biochem. 2:691-696.

Dyer, W. J., F. E. Dyer, and J. M. SNow. 1952. Amines in fish muscle. V. Trimethylamine oxide estimation. J. Fisheries Res. Board Can. $8(5): 309-313$.

ENGELHARDT, R. 1913. Monographie der Selachier der Münchener zoologischen Staatssammlung. I. Tiergeographie der Selachier. Abhandl. Bayerischen Akad. Wiss. 4(3):1-110.

FEaron, W. 1939. The carbamido diacetyl reaction: a test for citrulline. Biochem. J. 33:902907.

Fiske, C. H., and Y. Subbarow. 1925. The colorimetric determination of phosphorus. J Biol. Chem. 66:375-400.

Garrick, J. A. F., and L. P. Schultz. 1963. A guide to the kinds of potentially dangerous sharks. In P. W. Ginbert (ed.), Sharks and survival. Heath, Lexington, Mass.

Gerzelli, G., M. V. Gervaso, and G. F. De Stefano. 1969. Aspetti della ghiandola rettale e della regolazione osmotica in Selaci marini e d'acqua dolce. Atti 38 Convegno U.Z.I., Senigallia, Boll. Zool. 36.

Girbert, P. W., R. F. Mathewson, and D. P. RALL. 1967. Sharks, skates, and rays. Johns Hopkins Press, Baltimore. 624 pp.

Goldstein, L., and R. P. Forster. 1971a. Osmoregulation and urea metabolism in the little skate Raja erinacea. Amer. J. Physiol. 220: 742-746.

- 1971b. Urea biosynthesis and excretion in freshwater and marine elasmobranchs. Comp. Biochem. Physiol. 39B:415-421.

GoldstenN, L., W. W. Oppelt, and T. H. Maren. 1968. Osmotic regulation and urea metabolism in the lemon shark Negaprion brevirostris. Amer. J. Physiol. 215:1493-1497.

Hartman, F. A., L. A. Lewis, K. A. Browneli, F. F. Sheldon, and R. F. Walther. 1941. Some blood constituents of the normal skate. Physiol. Zoöl. 14:476-486.

Heagy, F. C. 1948. Determination of magnesium in body fluids by the use of Titan Yellow. Can. J. Res. 26E:295.

Hoar, W. S., and D. J. Randall. 1969. Fish physiology. Vol. 1. Excretion, ionic regulation, and metabolism. Academic Press, New York. $465 \mathrm{pp}$.

JENSEN, N. H. 1972. Reproduction and development of the bull shark, Carcharhinus leucas, in the Lake Nicaragua-Rio San Juan system. Unpublished Ph.D. thesis. University of $\mathrm{Ne}$ braska, Lincoln, Nebraska.

KROGH, A. 1939. Osmotic regulation in aquatic animals. Cambridge Univ. Press, Cambridge. $242 \mathrm{pp}$.

MAREN, T. H. 1967. Special body fluids of the elasmobranch. In P. W. GILBERT, R. F. Mathewson, and D. P. RaLl (eds.), Sharks, skates, and rays. Johns Hopkins Press, Baltimore.

MuRdaugh, H. V., and E. D. Robin. 1967. Acidbase metabolism in the dogfish shark. In P. W. GILbert, R. F. Mathewson, and D. P. Rall (eds.), Sharks, skates, and rays. Johns Hopkins Press, Baltimore.

OGURI, M. 1964. Rectal glands of marine and fresh-water sharks: comparative histology. Science 144:1151-1152.

Oppelt, W. W., C. S. Patlak, C. G. Zubrod, and D. P. RALL. 1964. Ventricular fluid production rates and turnover in elasmobranchii. Comp. Biochem. Physiol. 12:171-177.

Potts, W. T. W., and G. Parry. 1964. Osmotic and ionic regulation in animals. Macmillan, New York. 423 pp.

Price, K. S., and E. P. Creaser, Jr. 1967. Fluctuations in two osmoregulatory components, urea and sodium chloride, of the clearnose skate, Raja eglanteria Bosc 1802-I. Upon laboratory modification of external salinities. Comp. Biochem. Physiol. 23:65-76.

Prosser, C. L., and F. A. Brown, JR. 1961. Comparative animal physiology. Saunders, Philadelphia. 688 pp.

Rodnan, G. P., E. D. Robin, and M. H. Andrus 1962. Dogfish coelomic fluid. I. Chemical anatomy. Bull. Mount Desert Island Biol. Lab. 4(4):69.

Schales, O., and S. S. Schales. 1941. A simple and accurate method for the determination of chloride in biological fluids. J. Biol. Chem. 140:879-884.

SCRIBner, B. H., and J. CaIllouette. 1954. Serum bicarbonate: bedside determinant. J. Amer. Med. Ass. 155:644.

SmitH, H. W. 1929. The composition of the body fluids of elasmobranchs. J. Biol. Chem. 81: 407-419.

- 1931a. The absorption and excretion of water and salts by the elasmobranch fishes. I. Fresh water elasmobranchs. Amer. J. Physiol. 98:279-295.

. 1931b. The absorption and excretion of water and salts by the elasmobranch fishes. II. Marine elasmobranchs. Amer. J. Physiol. 98: 296-310. 
- 1936. The retention and physiological role of urea in the elasmobranchii. Biol. Rev. 11: $49-82$.

Staedeler, G., and F. T. Frerichs. 1858. Utber das Vorkommen von Harnstoff, Taurin und Scyllit in den Organen der Plagiostomen. J. Prakt. Chem. 73:48-55.

Thorson, T. B. 1961. The partitioning of body water in Osteichthyes: phylogenetic and ecological implications in aquatic vertebrates. Biol. Bull. 120:238-254.

1962a. Body water partitioning of the fresh water shark, Carcharhinus nicaraguensis, compared with that of marine selachians. Amer. Zool. 2(3):452-453.

- 1962b. Partitioning of body fluids in the Lake Nicaragua shark and three marine sharks. Science 138: 688-690.

- - 1967. Osmoregulation in fresh water elasmobranchs. In P. W. GILberT, R. F. Mathewson, and D. P. RaLl (eds.), Sharks, skates, and rays. Johns Hopkins Press, Baltimore.

- - 1970. Freshwater stingrays, Potamotrygon spp.: failure to concentrate urea when exposed to saline medium. Life Sci. 9:893-900.

_- 1971. Movement of bull sharks, Car- charhinus leucas, between Caribbean Sea and Lake Nicaragua demonstrated by tagging. Copeia 1971:336-338.

Thorson, T. B., C. M. Cowan, and D. E. Watson. 1967. Potamotrygon spp.: elasmobranchs with low urea content. Science 158:375-377. Thorson, T. B., and J. W. Gerst. 1972. Comparison of some parameters of serum and uterine fluid of pregnant, viviparous sharks ( $\mathrm{Car}$ charhinus leucas) and serum of their near-term young. Comp. Biochem. Physiol. 42A:33-40.

Thorson, T. B., D. E. Watson, and C. M. Cowan. 1966. The status of the freshwater shark of Lake Nicaragua. Copeia 1966:385402 .

URIST, M. R. 1962. Calcium and other ions in blood and skeleton of Nicaraguan fresh-water shark. Science 137:984-986.

Warts, D. C., and R. L. Watts. 1966. Carbamoyl phosphate synthetase in the elasmobranchii: osmoregulatory function and evolutionary implications. Comp. Biochem. Physiol. 17:785798.

Weichselbaum, T. E. 1946. An accurate and rapid method for the determination of proteins in small amounts of blood serum and plasma. Amer. J. Clin. Path. 7:40-49. 